\title{
Upaya meningkatkan hasil belajar lompat jauh gaya menggantung melalui alat bantu
}

\author{
Dwi Adya Prihandana \\ Universitas Negeri Yogyakarta. Jl. Colombo No. 1 Yogyakarta, 55281, Indonesia \\ Email:2prihandana@gmail.com
}

\begin{abstract}
Abstrak
Penelitian ini merupakan penelitian tindakan kelas (PTK). Penelitian ini dilaksanakan dalam dua siklus, dengan tiap siklus terdiri atas perencanaan, pelaksanaan tindakan, observasi, dan refleksi. Subjek penelitian adalah siswa Kelas XII TGB SMK Negeri 1 sedayu yang berjumlah 31 siswa. Teknik pengumpulan data adalah dengan observasi, wawancara dan tes. Analisis data menggunakan teknik analisis deskriptif kualitatif. Dari hasil analisis, terjadi peningkatan yang signifikan pada prasiklus ke siklus I dan dari siklus I ke siklus II. Pada prasiklus hasil belajar lompat jauh gaya menggantung peserta didik kategori cukup 25,8\%, kurang $64,5 \%$ dan sangat kurang 9,7\%. Dalam prasiklus jumlah peserta didik yang tuntas adalah 8 peserta didik. Sedangkan pada Siklus I, kategori baik sebesar $22,5 \%$, cukup $32,2 \%$, kurang $42 \%$ dan kurang sekali 3,2\%. Dalam Siklus I jumlah peserta didik yang tuntas adalah 17 peserta didik. Pada siklus II, kategori sangat baik sebesar $6,4 \%$, baik 35,5\%, cukup 38,7\% dan kurang $19,4 \%$. Dalam Siklus II jumlah peserta didik yang tuntas adalah 25 peserta didik. Pelaksanaan Siklus II menyebabkan hasil belajar lompat jauh gaya menggantung meningkat menjadi lebih baik. Kesimpulan penelitian ini adalah dengan penerapan alat bantu mampu meningkatkan hasil belajar lompat jauh gaya menggantung.
\end{abstract}

Kata kunci: lompat jauh gaya menggantung, alat bantu, hasil belajar

\section{Efforts to improve learning outcomes style long jump hang through a tool}

Abstract

This research is a classroom action research (CAR). This research was conducted in two cycles, with each cycle consisting of planning, action, observation and reflection. The research subjects were students of Class XII TGB of SMK Negeri 1 Sedayu which numbered 31 students. Data collection techniques are by observation, interviews and tests. Data analysis used qualitative descriptive analysis techniques. From the results of the analysis, there was a significant increase in pre-cycle to cycle I and from the cycle I to cycle II. In the cycle of learning outcomes, the hanging style long jump of the students is quite $25.8 \%$, less $64.5 \%$ and very less $9.7 \%$. In the pre-cycle, the number of complete students is eight students. Whereas in Cycle I, the good category was $22.5 \%$, enough $32.2 \%$, less $42 \%$ and less $3.2 \%$. In Cycle I the number of students who completed was 17 students. In the second cycle, the excellent category was $6.4 \%$, good $35.5 \%$, enough $38.7 \%$ and less $19.4 \%$. In Cycle II the total number of students who completed was 25 students. The implementation of Cycle II caused the learning outcomes of the hanging style long jump to improve for the better. The conclusion of this study is that the application of assistive devices can improve the learning outcomes of hanging style long jumps.

Keywords: hanging style long jump, assistive devices, learning outcomes

\section{PENDAHULUAN}

Pendidikan jasmani olahraga dan kesehatan merupakan bagian dari pendidikan secara keseluruhan, bertujuan untuk mengembangkan aspek kebugaran jasmani, keterampilan 
gerak, keterampilan berfikir kritis, keterampilan sosial, penalaran, stabilitas emosional, tindakan moral, aspek pola hidup sehat dan pengenalan lingkungan bersih melalui aktivitas jasmani, olahraga dan kesehatan terpilih yang direncanakan secara sistematis dalam rangka mencapai tujuan pendidikan nasional.

Pendidikan jasmani olahraga dan kesehatan merupakan media untuk mendorong pertumbuhan fisik, perkembangan psikis, keterampilan motorik, pengetahuan dan penalaran, penghayatan nilai-nilai (sikap, mental, emosional, sportivitas, spiritual, sosial), serta pembiasaan pola hidup sehat yang bermuara untuk merangsang pertumbuhan dan perkembangan kualitas fisik dan psikis yang seimbang. Melalui pendidikan jasmani anak didik akan memperoleh berbagai pengalaman terutama yang sangat erat kaitannya dengan kesan pribadi yang menyenangkan, berbagai ungkapan yang kreatif, inovatif, keterampilan gerak, kebugaran jasmani, membiasakan hidup sehat, pengetahuan dan pemahaman terhadap sesama manusia.

Atletik adalah salah satu cabang olahraga yang tertua yang dilakukan oleh manusia sejak jaman Yunani Kuno. Dalam mata pelajaran atletik yang dipelajari adalah gerakan dasar manusia di dalam kehidupan sehari-hari, yaitu berjalan, berlari, melompat dan melempar. Dari keempat nomor atletik tersebut yang akan dibahas lebih lanjut adalah pada nomor lompat jauh. Lompat jauh adalah salah satu nomor lompat dari cabang olahraga atletik. lompat jauh adalah keterampilan gerak berpindah dari satu tempat ke tempat lainnya dengan satu kali tolakan ke depan sejauh mungkin.

Agar pembelajaran nomor-nomor lompat itu dapat berhasil dengan baik, maka unsurunsur bermain dan juga kreativitas dalam pembelajaran harus menjadi pokok pertimbangan penyelenggaraan. Pembelajaran lompat yang menggunakan media pembelajaran yang inovatif, memungkinkan anak untuk lebih termotivasi dalam melakukan kegiatan belajar mengajar. Dalam proses pembelajaran pendidikan jasmani ada tiga tahapan yang harus dilakukan yaitu: tahap pendahuluan, tahap inti dan tahap penutup.

Dilain pihak melalui hasil pengamatan dan observasi siswa dalam pembelajaran lompat jauh di SMK Negeri 1 Sedayu sudah berjalan, tapi belum menunjukan hasil yang maksimal. Dari nilai KKM 75 yang ditentukan, hanya 8 siswa yang mencapai nilai tersebut. Sedangkan 23 Siswa yang lain belum bisa memenuhi nilai KKM. Tidak semua siswa dapat menguasai gerakan lompat jauh gaya menggantung dengan baik dan benar. Rendahnya kemampuan siswa menunjukan adanya kelemahan sekaligus kesulitan belajar mengajar lompat jauh.

Oleh karena itu perlu adanya solusi untuk mengatasi permasalahan tersebut di atas. Dan salah satu solusinya adalah dengan menggunakan alat bantu pembelajaran. Dengan metode tersebut diharapkan siswa SMK Negeri 1 Sedayu mampu melakukan gerakan lompat jauh gaya menggantung dengan antusias dan baik. Untuk mengetahui bagaimana modifikasi alat bantu ini mampu mempengaruhi kemampuan siswa maka perlu dilakukan sebuah penelitian tindakan kelas dengan judul, "Upaya Meningkatkan Hasil Belajar Lompat JauhGaya Menggantung Melalui Alat Bantu Pada Siswa Kelas XII TGB SMK Negeri 1 Sedayu Tahun Ajaran 2017/2018"

Lompat jauh merupakan rangkaian gerakan berupa teknik gerakan yang tujuan untuk menghasilkan lompatan sejauh kedepan. Hasil lompat jauh didapat dari awalan lari yang cepat dan mampu diubah menjadi kemampuan melompat melalui tolakan dan melayang di udara dengan teknik yang benar diakhiiri dengan pendaratan dengan sempurna menurut Hadziq (2013). Teknik gerak dalam lopat jauh adalah awalan, tolakan, melayang di udara dan pendaratan.

\section{Teknik Lompat Jauh Gaya Menggantung}

Purnomo (2011) mengutarakan Gaya menggantung (hang style), lutut kaki bebas (ayun) diturunkan tepat setelah menumpu dan lutut ditekuk membentuk sudut $90^{\circ}$. Pada saat kaki tumpu bergabung dengan kaki bebas (ayun), kedua lutut juga ditekuk. Kedua lengan harus diangkat sampai posisi di atas kepala. Dengan hasil posisi cekung punggung menarik terhadap pinggul pelompat mulai persiapan untuk pendaratan. Posisi menggantung ini dipertahankan sampai kira-kira setengah panjang melayang (lintasan Parabol). Selanjutnya 
persiapan ini termasuk ayunan ke depan tubuh bagian atas, pelurusan ke depan dari kedua lengan dan pengangkatan dari tungkai bawah. Untuk lebih jelas lihat gambar.

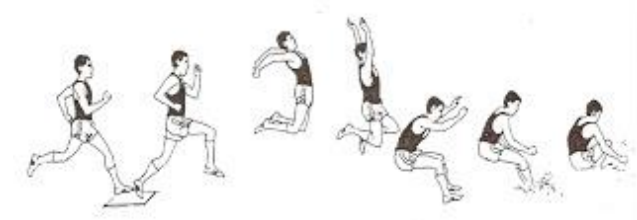

\section{Gambar 1: Lompat Jauh Gaya Menggantung}

Lari awalan pada lompat jauh dilakukan engan berlari dengan kecepatan yang meningkat secara bertahap hingga kecepatan maksimal. Hadziq (2013) menyatakan bahwa awalan adalah ada tiga sampai lima langkah terahir, pelompat mempersiakan tolakan. Tolakan yang dilakukan yaitu pada saat lari awalan mencapai kecepatan tertinggi, pencapaian kecepatan tergantung pada kemampuan masing-masing siswa. Tambah kecepatan lari ancang-ancang sedikit demi sedikit sebelum bertumpu atau bertolak. Pinggang diturunkan sedikit pada satu langkah akhir ancang-ancang. Tolakan merupakan tahapan perpindahan dan pengubahan kecepatan lari awalan menjadi kemampuan melompat. Posisi kaki yang melakukan tolakan sedikit menekuk, diikuti oleh kaki satunya dari belakang mengayun ke depan, kemudian menolak kuat dengan meluruskan kaki tolakan dan mengayun kedua lengan kedepan atas (Hadziq, 2013). Gerakan tolakan dimulai dari menapakkan kaki, mendorong dan meluruskan tungkai untuk menolak. Ayunkan pada kaki ke posisi horizontal dan dipertahankan. Luruskan sedikit mata kak, lutut, dan pinggang pada melakukan tolakan.

Tahapan melayang tahapan pertama saat melayang, tubuh bagian atas dipertahankan agar tetap tegak dan gerakan lengan atas menggambarkan semi sirkel dari depan atas terus ke bawah dan kedepan (Purnomo, 2007). Sedangkan tahap mendarat dilakukan dua kaki lurus ke depan dengan rileks, hidari bagian tubuh lain menyentuh pasir lebih belakang dari kaki, karena hal tersebut akan mengurangi pengukuran hasil lompatan. Untuk menghindari jatuhnya tangan atau pantat terlebih dahul, kedepan ditundukan dan jangan diayunkan ke depan, sehingga pinggang dan titik berat badan terbawa ke depan (Hadziq, 2013).

\section{Hasil Belajar}

Hasil belajar adalah pencapaian bentuk perubahan prilaku belajar, yaitu kognitif, afektif dan psikomotor. Menurut Jihad dan Haris (2008) mengutip dari usman (2001) berpendapat bahwa, "Hasil belajar yang dicapai sangat erat kaitannya dengan rumusan tujuan instruksional yang direncanakan oleh guru sebelumnya yang diklompokan kedalam tiga kategori, yakni domain kognitif, afektif dan psikomotor". Untuk memperoleh hasil belajar perlu adanya suatu evaluasi untuk mengukur tingkat penguasaan siswa. Prestasi siswa tidak hanya diukur dari segi penguasaan ilmunya saja melainkan mencakup sikap dan keterampilan yang dimiliki siswa. Dengan demikian penilaian hasil siswa mencakup segala sesuatu yang dipelajari di sekolah.

\section{Alat Bantu Pembelajaran}

Alat bantu merupakan hal yang mampu membantu seorang guru untuk meningkatkan hasil belajar siswa. Karena dengan alat bantu, akan meningkatkan semangat dan motivasi siswa dalam mengikuti pembelajaran. Siswa akan tertarik dan menjadi lebih fokus dalam memperhatikan guru saat menjelaskan materi. Media sebagai alat bantu dalam proses belajar mengajar adalah suatu kenyataan yang tidak dapat dipungkiri. Karena memang gurulah yang menghendakinya untuk membantu tugas guru dalam menyampaikan pesan- pesan dari bahan pelajaran yang diberikan oleh guru kepada anak didik (Djamarah dan Zain, 2010).

Alat pembelajaran yang dapat digunakan oleh guru pendidikan jasmani dalam lompat jauh banyak jenisnya, dalam hal ini peneliti menggunakan alat bantu kardus dan bola gantung. Kardus digunakan sebagai rintangan siswa agar siswa mampu melakukan lompatan secara maksimal. Sedangkan bola yang dikaitkan pada tiang. Bola digantungkan pada tali. Bola 
gantung ini digunakan pada saat siswa melakukan lompatan siswa harus mampu meraih bola dengan kedua tangan. Hal ini bertujuan agar siswa mampu melakukan gerakan lompat jauh gaya menggantung lebih maksimal.

\section{METODE}

Penelitian ini dilaksanakan di SMK Negeri 1 Sedayu. Pemilihan tempat didasarkan atas pertimbangan ketersediaan sarana khususnya lompat jauh yang memungkinkan untuk digunakan sebagai tempat penelitian. Penelitian ini dilaksanakan selama 4 bulan, yaitu bulan Agustus sampai November 2017 (selama peneliti melaksanakan kegiatan praktik pengalaman lapangan/PPL). Subyek penelitian ini adalah siswa kelas kelas XIITGB SMK Negeri 1 Sedayu dengan jumlah siswa 31 siswa yang terdiri dari 20 siswa putra dan 11 siswa putri.

Penelitian ini dilaksanakan dalam dua siklus, dengan tiap siklus terdiri atas perencanaan, pelaksanaan tindakan, observasi, dan refleksi. Pada siklus I dilaksanakan beberapa tahap perencanaan, yaitu tim peneliti melakukan analisis kurikulum untuk mengetahui kompetensi dasar yang akan disampaikan siswa dalam pembelajaran penjasorkes. Membuat rencana pelaksanaan pembelajaran (RPP) dengan mengacu pada tindakan yang diterapkan dalam PTK, yaitu pembelajaran lompat jauh gaya menggantung menggunakan alat bantu bola gantung. Menyusun instrumen yang digunakan dalam siklus PTK, penilaian lompat jauh gaya menggantung. Peneliti menyiapkan media yang diperlukan untuk membantu pengajaran, serta menyusun alat evaluasi pembelajaran.

Pada tahap pelaksanan, kegiatan yang dilakukan adalah melaksanakan proses pembelajaran di lapangan dengan langkah-langkah kegiatan antara lain: menjelaskan kegiatan belajar mengajar lompat jauh gaya menggantung, melakukan pemanasan, melakukan gerakan lompat jauh gaya menggantung melalui penerapan alat bantu yang telah disiapkan oleh guru dan peneliti, menarik kesimpulan, penilaian dilaksanakan selama proses pembelajaran berlangsung, melakukan pendinginan.

Tahap pengamatan dilakukan terhadap antusias siswa dalam memperhatikan penjelasan guru dan dalam melakukan gerakan, serta kemampuan siswa dalam melakukan gerakan. Sedangkan tahap refleksi kegiatan yang dilakukan adalah mengolah, menganalisis dan mengecek kembali data-data yang telah dicatat baik pada lembar pengamatan maupun hasil pendokumentasian kegiatan pembelajaran lompat jauh gaya menggantung dengan modifikasi alat karet ban. Mengevaluasi data yang ada apakah terjadi hal-hal yang kurang atau tidak sesuai dengan yang diharapkan.

Pelaksanaan siklus II meliputi tahapan langkah-langkah seperti pada siklus I, tetapi berbeda bentuk dan sifat tindakan yang dilakukan. Siklus II ini merupakan perbaikan dan peningkatan dari siklus I dengan tetap mengacu pada hasil tindakan dan perbaikan pembelajaran yang ingin dicapai. Siklus III dilaksanakan apabila diperlukan.

\section{HASIL DAN PEMBAHASAN}

Kondisi hasil belajar lompat jauh gaya menggantung peserta didik kelas XII TGB SMK Negeri 1 Sedayu tahun ajaran 2017/2018 sebelum diberikan tindakan menggunakan alat bantu pembelajaran disajikan dalam bentuk tabel sebagai berikut:

Tabel 3. Diskripsi Data Awal Hasil Belajar Lompat Jauh

\begin{tabular}{cllcc}
\hline Rentang Nilai & \multicolumn{1}{c}{ Ket. } & \multicolumn{1}{c}{ Kriteria } & Jml Anak & $\%$ \\
\hline $91-100$ & Sangat Baik & Tuntas & 0 & 0 \\
$81-90$ & Baik & Tuntas & 0 & 0 \\
$75-80$ & Cukup & Tuntas & 8 & 25,8 \\
$60-74$ & Kurang & Belum Tuntas & 20 & 64,5 \\
$<60$ & Kurang sekali & Belum Tuntas & 3 & 9,7 \\
Jumlah & & & 31 & 100 \\
\hline
\end{tabular}

Berdasarkan hasil diskripsi data awal sebelum diberikan tindakan maka dapat dijelaskan bahwa mayoritas peserta didik belum menunjukkan hasil yang baik, prosentase peserta didik yang memenuhi ketuntasan 25,8 \% dengan kriteria cukup 25,8 \%, kurang 64,5\% dan kurang 
sekali 9,7\%. Dari diskripsi data awal yang diperoleh, masing-masing aspek menunjukan kriteria keberhasilan pembelajaran yang kurang sekali. Maka perlu dilakukan tindakan dalam rangka untuk memperbaiki dan meningkatkan hasil belajar peserta didik dalam proses pembelajaran lompat jauh gaya menggantung pada peserta didik kelas XII TGB SMK Negeri 1 Sedayu tahun pelajaran 2017/2018, dengan menggunakan alat bantu pembelajaran.

Dalam pelaksanaan Siklus I, peneliti dan guru melakukan pengambilan data. Adapun diskripsi data yang diambil terdiri dari tes kemampuan lompat jauh gaya menggantung (psikomotor) dan pemahaman konsep gerak (kognitif). Kondisi hasil belajar lompat jauh gaya menggantung Siklus I disajikan dalam bentuk tabel sebagai berikut:

Tabel 4. Diskripsi Siklus I Hasil Belajar Lompat Jauh

\begin{tabular}{cllcc}
\hline Rentang Nilai & \multicolumn{1}{c}{ Ket } & \multicolumn{1}{c}{ Kriteria } & Jml Anak & $\%$ \\
\hline $91-100$ & Sangat Baik & Tuntas & 0 & 0 \\
$81-90$ & Baik & Tuntas & 7 & 22,5 \\
$75-80$ & Cukup & Tuntas & 10 & 32,2 \\
$60-74$ & Kurang & Belum Tuntas & 13 & 42 \\
$<60$ & Kurang sekali & Belum Tuntas & 1 & 3,2 \\
Jumlah & & & 31 & 100 \\
\hline
\end{tabular}

Berdasarkan hasil diskripsi siklus pertama, hasil belajar peserta didik kelas XII TGB SMK Negeri 1 Sedayu tahun ajaran 2017/2018 adalah; baik dengan prosentase 22,5\%, cukup dengan prosentase $32,2 \%$, kurang dengan prosentase $42 \%$ dan kurang sekali dengan prosentase 3,2\%. Dari 31 peserta didik yang ada, 17 peserta didik telah mencapai kriteria tuntas sedangkan 14 peserta didik belum tuntas.

Dalam pelaksanaan Siklus II, peneliti dan guru melakukan pengambilan data. Adapun diskripsi data yang diambil terdiri dari tes kemampuan lompat jauh gaya menggantung (psikomotor) dan pemahaman konsep gerak (kognitif). Kondisi hasil belajar lompat jauh gaya menggantung Siklus II disajikan dalam bentuk tabel sebagai berikut:

Tabel 5: Diskripsi Siklus II Hasil Belajar Lompat Jauh

\begin{tabular}{cllcc}
\hline Rentang Nilai & \multicolumn{1}{c}{ Ket. } & \multicolumn{1}{c}{ Kriteria } & Jml Anak & $\%$ \\
\hline $91-100$ & Sangat Baik & Tuntas & 2 & 6,4 \\
$81-90$ & Baik & Tuntas & 11 & 35,5 \\
$75-80$ & Cukup & Tuntas & 12 & 38,7 \\
$60-74$ & Kurang & Belum Tuntas & 6 & 19,4 \\
$<60$ & Kurang sekali & Belum Tuntas & 0 & 0 \\
Jumlah & & & 31 & 100 \\
\hline
\end{tabular}

Berdasarkan hasil diskripsi siklus kedua, hasil belajar peserta didik kelas XII TGB SMK Negeri 1 Sedayu tahun ajaran 2017/2018 adalah; sangat baik dengan prosentase 6,4\%, baik dengan prosentase $35,5 \%$, cukup dengan prosentase $38,7 \%$, kurang dengan prosentase $19,4 \%$ dan kurang sekali dengan prosentase 0\%. Dari 31 peserta didik yang ada, 25 peserta didik telah mencapai kriteria tuntas sedangkan 6 peserta didik belum tuntas.

Perbandingan hasil belajar lompat jauh gaya menggantung peserta didik kelas XII TGB SMK Negeri 1 Sedayu tahun ajaran 2017/2018 pada akhir Siklus I dan Siklus II disajikan dalam bentuk tabel sebagai berikut:

Tabel 6: Diskripsi Perbandingan Hasil Belajar Lompat Jauh

\begin{tabular}{clccc}
\hline \multirow{2}{*}{ Rentang Nilai } & \multirow{2}{*}{ Ket. } & \multicolumn{3}{c}{ Prosentasi } \\
\cline { 3 - 5 } & Data Awal & Siklus I & Siklus II \\
\hline $91-100$ & Sangat Baik & $0 \%$ & $0 \%$ & $6,4 \%$ \\
$81-90$ & Baik & $0 \%$ & $22,5 \%$ & $35,5 \%$ \\
$75-80$ & Cukup & $25,8 \%$ & $32,2 \%$ & $38,7 \%$ \\
$60-74$ & Kurang & $64,5 \%$ & $42 \%$ & $19,4 \%$ \\
$<60$ & Kurang sekali & $9,7 \%$ & $3,2 \%$ & $0 \%$ \\
\hline
\end{tabular}


Berdasarkan hasil pelaksanaan penelitian tindakan kelas pada siklus I dan II dapat disimpulkan bahwa terjadi peningkatan hasil belajar lompat jauh gaya menggantung pada peserta didik kelas XII TGB SMK Negeri 1 Sedayu tahun ajaran 2017/2018. Dari hasil analisis, terjadi peningkatan yang signifikan pada prasiklus ke siklus I dan dari siklus I ke siklus II. Pada Prasiklus hasil belajar lompat jauh gaya menggantung peserta didik kategori cukup 25,8\%, kurang $64,5 \%$ dan sangat kurang 9,7\%. Dalam Prasiklus jumlah peserta didik yang tuntas adalah 8 peserta didik. Sedangkan pada Siklus I hasil belajar lompat jauh gaya menggantung peserta didik pada kategori baik sebesar $22,5 \%$, cukup $32,2 \%$, kurang $42 \%$ dan kurang sekali $3,2 \%$. Dalam Siklus I jumlah peserta didik yang tuntas adalah 17 peserta didik. Dan pada siklus II hasil belajar lompat jauh gaya menggantung peserta didik pada kategori sangat baik sebesar $6,4 \%$, baik $35,5 \%$, cukup 38,7\% dan kurang 19,4\%. Dalam Siklus II jumlah peserta didik yang tuntas adalah 25 peserta didik. Pada Siklus I terjadi peningkatan hasil belajar lompat jauh gaya menggantung walaupun kurang signifikan. Sedangkan pada pelaksanaan Siklus II terjadi peningkatan lompat jauh gaya menggantung yang lebih signifikan. Lebih banyak peserta didik yang memenuhi standar ketuntasan.

\section{SIMPULAN}

Penelitian Tindakan Kelas pada siswa kelas XIII TGB SMK Negeri 1 Sedayu tahun ajaran 2017/2018 dilaksanakan dalam dua siklus. Setiap siklus terdiri ata dua pertemuan. Dalam siklus terdapat empat tahapan, yaitu: (1) perencanaan, (2) pelaksanaan tindakan, (3) observasi dan interpretasi, dan (4) analisis dan refleksi. Dari hasil analisis data, diperoleh peningkatan yang signifikan pada siklus I dan siklus II. Hasil belajar lompat jauh gaya menggantung pada siklus I dalam kategori tuntas adalah $54,6 \%$ atau 17 siswa. Pada siklus II terjadi peningkatan prosentase hasil belajar siswa dalam kategori tuntas sebesar $80,6 \%$ atau sejumlah 25 siswa. Dengan demikian, dapat disimpulkan bahwa alat bantu kardus dan bola gantung dapat meningkatkan hasil belajar lompat jauh gaya menggantung siswa kelas XIII TGB SMK Negeri 1 Sedayu tahun ajaran 2017/2018.

\section{DAFTAR PUSTAKA}

Arikunto, S., Suhardjono, dan Supardi. (2007). Penelitian tindakan kelas. Jakarta: Bumi Aksara.

Ekawarna. (2009). Penelitian tindakan kelas. Jakarta: Gaung Persada.

Hadziq, K. (2013). Pendidikan jasmani olahraga dan kesehatan untuk SMA-MA/SMK kelas $X$, kurikulum 2013. Bandung: PT. Yrama Widya.

Furqon H.M. (2006). Mendidik anak dengan bermain. Surakarta: Universitas Sebelas Maret.

Mulyasa H.E. (2009). Praktik penelitian tindakan kelas. Bandung: PT. Remaja Rosdakarya.

Permendikbud tahun 2014 no 104. Peraturan menteri pendidikan dan kebudayaan Republik Indonesia.

Purnomo. E, Dapan. (2011). Dasar-dasar gerakan atletik. Yogyakarta: Alfamedia.

Pardjono. (2007). Panduan penelitian tindakan kelas. Yogyakarta: Lembaga Penelitian Universitas Negeri Yogyakarta.

Saputra, Y.P. (2001). Dasar-dasar keterampilan atletik. Jakarta: Direktorat Jenderal Pendidikan Dasar \& Menengah.

Winarno, M.E. (2007). Metodologi penelitian dalam pendidikan jasmani. Malang: Universitas Negeri Malang. 